Dieses Dokument ist eine Zweitveröffentlichung (Verlagsversion) / This is a self-archiving document (published version):

Yanping Tang, Dongqing Wu, Yiyong Mai, Hao Pan, Jing Cao, Chongqing Yang, Fan Zhanga, Xinliang Feng

\title{
A two-dimensional hybrid with molybdenum disulfide nanocrystals strongly coupled on nitrogen-enriched graphene via mild temperature pyrolysis for high performance lithium storage
}

Erstveröffentlichung in / First published in:

Nanoscale. 2014, 6(24), S. 14679-14685 [Zugriff am: 04.11.2019]. Royal Society of Chemistry. ISSN 2040-3372.

DOI: https://doi.org/10.1039/c4nro5519e

Diese Version ist verfügbar / This version is available on:

https://nbn-resolving.org/urn:nbn:de:bsz:14-qucosa2-363113

„Dieser Beitrag ist mit Zustimmung des Rechteinhabers aufgrund einer (DFGgeförderten) Allianz- bzw. Nationallizenz frei zugänglich."

This publication is openly accessible with the permission of the copyright owner. The permission is granted within a nationwide license, supported by the German Research Foundation (abbr. in German DFG).

www.nationallizenzen.de/ 


\section{Nanoscale}

\section{COMMUNICATION}

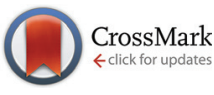

Cite this: Nanoscale, 2014, 6, 14679

Received 21st September 2014, Accepted 20th October 2014

DOI: $10.1039 / c 4 n r 05519 e$

www.rsc.org/nanoscale

\section{A two-dimensional hybrid with molybdenum disulfide nanocrystals strongly coupled on nitrogen-enriched graphene via mild temperature pyrolysis for high performance lithium storage $\uparrow$}

\author{
Yanping Tang, ${ }^{a}$ Dongqing Wu, ${ }^{a}$ Yiyong Mai, ${ }^{a}$ Hao Pan, ${ }^{a}$ Jing Cao, ${ }^{a}$ \\ Chongqing Yang, ${ }^{a}$ Fan Zhang ${ }^{a}$ and Xinliang Feng ${ }^{\text {a,b }}$
}

\begin{abstract}
A novel 2D hybrid with $\mathrm{MoS}_{2}$ nanocrystals strongly coupled on

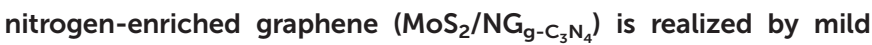
temperature pyrolysis $\left(550{ }^{\circ} \mathrm{C}\right)$ of a self-assembled precursor $\left(\mathrm{MoS}_{3} / \mathrm{g}-\mathrm{C}_{3} \mathrm{~N}_{4}-\mathrm{H}^{+} / \mathrm{GO}\right)$. With rich active sites, the boosted electronic conductivity and the coupled structure, $\mathrm{MoS}_{2} / \mathrm{NG}_{\mathrm{g}-\mathrm{C}_{3} \mathrm{~N}_{4}}$ achieves superior lithium storage performance.
\end{abstract}

Nowadays, portable electronics and commercial electric vehicles (EVs) are mostly powered by lithium ion batteries (LIBs). ${ }^{1}$ However, the energy and power densities of LIBs with a conventional graphite anode still lag behind the increasing requirements. The emergence of graphene with excellent charge carrier mobility, large specific surface area and strong mechanical properties ${ }^{2}$ has provided amazing opportunities for high performance LIBs, as it can serve as an intriguing two-dimensional (2D) platform to hybridize with various lithium storage components. ${ }^{3-6}$ In particular, nitrogen doping confers an important strategy to impart graphene with enhanced electronic conductivity, additional active sites for lithium storage, and improved affinity to other integrants. ${ }^{7-13}$ Diverse approaches have been developed to dope nitrogen into carbon networks including chemical vapor deposition (CVD), ${ }^{8,9,14}$ plasma treatment, ${ }^{15,16}$ arc-discharge,${ }^{17}$ hydrothermal process, ${ }^{12,13,18-21}$ and thermal conversion of nitrogen-rich precursors. ${ }^{7,10,11,22-28}$ Nevertheless, harsh conditions such as high temperature $\left(700-1100{ }^{\circ} \mathrm{C}\right),{ }^{8-11,14,17,22-28}$ high vacuum, ${ }^{7,15,16}$ or high pressure ${ }^{12,13,18-21}$ are generally required in these methods. Meanwhile, the nitrogen content in graphene is usually lower than 10 at\%. Thereby, the scalable production of

\footnotetext{
${ }^{a}$ School of Chemistry and Chemical Engineering, Shanghai JiaoTong University, 200240 Shanghai, China.E-mail: wudongqing@sjtu.edu.cn

${ }^{b}$ Department of Chemistry and Food Chemistry, Technische Universitaet Dresden, 01062 Dresden, Germany.E-mail: xinliang.feng@tu-dresden.de

$\dagger$ Electronic supplementary information (ESI) available: Photo images, Zeta potential, additional SEM, TEM, HRTEM and AFM images, XRD, FTIR, TGA under N2, TGA under air, pore size distribution, additional XPS are presented. $\mathrm{N}$ doping conditions, cycling/rate performances are listed in tables. See DOI: 10.1039/c4nr05519e
}

hybrids based on nitrogen-enriched graphene remains a big challenge.

With favorable interlayer spacing for Li insertion/extraction, molybdenum disulfide $\left(\mathrm{MoS}_{2}\right)$, a layered transition metal dichalcogenide, is regarded as a promising candidate to compose graphene-based hybrids as anode materials in LIBs. $^{29}$ Along this line, various hybrids with $\mathrm{MoS}_{2}$ and graphene nanosheets have been fabricated via methods including exfoliation and restacking, ${ }^{30-32} \mathrm{CVD}^{33}$ and hydrothermal reaction. ${ }^{11,34-39}$ However, insufficient Li storage sites and the poor intrinsic electrical conductivity among $\mathrm{MoS}_{2}$ layers are still difficult to conquer, hampering their electrochemical performances in LIBs. Thus, the integration of nanosized $\mathrm{MoS}_{2}$ on N-doped graphene with strong synergies is envisioned to provide rich lithium storage sites and the coupled structure with the enhanced conductivity for high cycling/rate performance.

In this work, we demonstrate an efficient approach towards a novel 2D mesoporous nanohybrid with $\mathrm{MoS}_{2}$ nanocrystals strongly coupled on nitrogen-enriched graphene $\left(\mathrm{MoS}_{2} /\right.$ $\mathrm{NG}_{\mathrm{g}^{-} \mathrm{C}_{3} \mathrm{~N}_{4}}$ ), which is derived from the mild temperature pyrolysis $\left(550{ }^{\circ} \mathrm{C}\right)$ of the self-assembled tri-constituent composite with molybdenum trisulfide $\left(\mathrm{MoS}_{3}\right)$, protonated graphitic carbon nitride $\left(\mathrm{g}-\mathrm{C}_{3} \mathrm{~N}_{4}-\mathrm{H}^{+}\right)$and graphene oxide (GO). During the thermal treatment, $\mathrm{g}-\mathrm{C}_{3} \mathrm{~N}_{4}-\mathrm{H}^{+}$effectively assists the formation of highly crystallized $\mathrm{MoS}_{2}$ nanoplatelets with sizes smaller than $10 \mathrm{~nm}$ and (002) $d$-spacing of $0.66 \mathrm{~nm}$ vertically exposed on the graphene surface, resulting in a mesoporous structure with a high specific surface area and a large pore volume $\left(109 \mathrm{~m}^{2} \mathrm{~g}^{-1}, 0.883 \mathrm{~cm}^{3} \mathrm{~g}^{-1}\right)$ of the 2D hybrid. Simultaneously, molybdenum sulfide promotes the complete decomposition of $\mathrm{g}-\mathrm{C}_{3} \mathrm{~N}_{4}-\mathrm{H}^{+}$at mild temperature and thereby imparts graphene with a high content of $\mathrm{N}$ dopants (ca. 13 at.\%), rendering greatly enhanced coupling of $\mathrm{MoS}_{2}$ on the N-enriched graphene and boosting the conductivity of the hybrid. As a consequence, $\mathrm{MoS}_{2} / \mathrm{NG}_{\mathrm{g}-\mathrm{C}_{3} \mathrm{~N}_{4}}$ manifests the outstanding reversible capacity ( $1450 \mathrm{~mA} \mathrm{~h} \mathrm{~g}^{-1}$ at $0.1 \mathrm{~A} \mathrm{~g}^{-1}$ ) for 200 cycles and exceptional rate capability $\left(1200 \mathrm{~mA} \mathrm{~h} \mathrm{~g}^{-1}\right.$ at $1 \mathrm{~A} \mathrm{~g}^{-1}, 830 \mathrm{~mA} \mathrm{~h} \mathrm{~g}{ }^{-1}$ at 


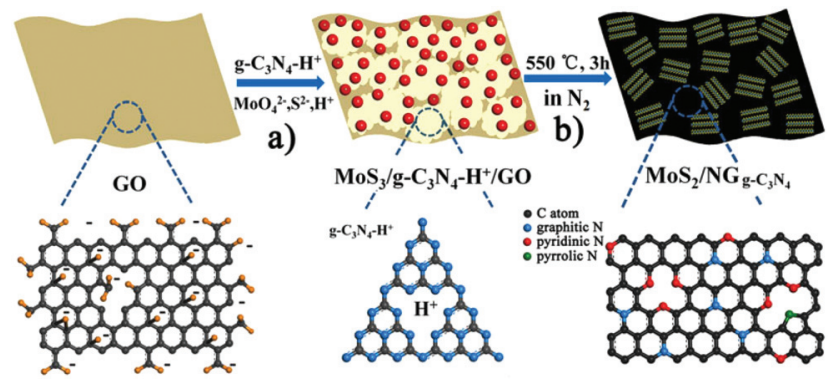

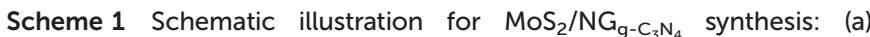
growth of $\mathrm{MoS}_{3}$ nanoparticles on the assembled $\mathrm{GO}$ and $\mathrm{g}-\mathrm{C}_{3} \mathrm{~N}_{4}-\mathrm{H}^{+}$ nanosheets to obtain $\mathrm{MoS}_{3} / \mathrm{g}-\mathrm{C}_{3} \mathrm{~N}_{4}-\mathrm{H}^{+} / \mathrm{GO}$; (b) thermal treatment of

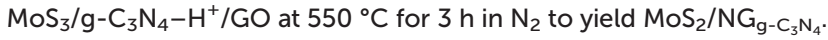

$10 \mathrm{~A} \mathrm{~g}^{-1}$ ) as an anode in LIBs, outperforming those of the prepared $\mathrm{MoS}_{2} / \mathrm{G}, \mathrm{MoS}_{2} / \mathrm{NGurea}$ using urea as a nitrogen source, as well as previously reported $\mathrm{MoS}_{2} / \mathrm{C},{ }^{40-43} \mathrm{MoS}_{2} /$ graphene, ${ }^{30-39} \mathrm{MoS}_{2} / \mathrm{N}$-doped graphene, ${ }^{11} \mathrm{~N}$-doped graphene based metal oxides. ${ }^{10,12,13}$

The overall synthetic procedure of $\mathrm{MoS}_{2} / \mathrm{NG}_{\mathrm{g}-\mathrm{C}_{3} \mathrm{~N}_{4}}$ is illustrated in Scheme 1. Polycondensation of urea at $550{ }^{\circ} \mathrm{C}$ led to the formation of $\mathrm{g}^{-} \mathrm{C}_{3} \mathrm{~N}_{4}$, which was then treated with $\mathrm{HCl}$ to produce protonated $\mathrm{g}-\mathrm{C}_{3} \mathrm{~N}_{4}\left(\mathrm{~g}-\mathrm{C}_{3} \mathrm{~N}_{4}-\mathrm{H}^{+}\right)$nanosheets. ${ }^{46-48}$ GO and $\mathrm{g}-\mathrm{C}_{3} \mathrm{~N}_{4}-\mathrm{H}^{+}$were flocculated together via sonication $\left(\mathrm{g}-\mathrm{C}_{3} \mathrm{~N}_{4}-\mathrm{H}^{+} / \mathrm{GO}\right)$ (Fig. S1 $\dagger$ ) and fed with $\mathrm{Na}_{2} \mathrm{MoO}_{4}$ to adsorb $\mathrm{MoO}_{4}{ }^{2-}$. After addition of $\mathrm{Na}_{2} \mathrm{~S}$ and $\mathrm{HCl}$, the tri-constituent aggregate of $\mathrm{MoS}_{3} / \mathrm{g}-\mathrm{C}_{3} \mathrm{~N}_{4}-\mathrm{H}^{+} / \mathrm{GO}$ was collected as precipitate and thermally treated at $550{ }^{\circ} \mathrm{C}$ in $\mathrm{N}_{2}$ for 3 hours to yield $\mathrm{MoS}_{2} / \mathrm{NG}_{\mathrm{g}-\mathrm{C}_{3} \mathrm{~N}_{4}}$. In controlled experiments, another hybrid of $\mathrm{MoS}_{2}$ on $\mathrm{N}$-doped graphene $\left(\mathrm{MoS}_{2} / \mathrm{NGurea}\right)$ was obtained by directly using urea as a nitrogen source, while a hybrid of $\mathrm{MoS}_{2}$ on graphene $\left(\mathrm{MoS}_{2} / \mathrm{G}\right)$ was prepared under the above conditions without involving $\mathrm{g}-\mathrm{C}_{3} \mathrm{~N}_{4}-\mathrm{H}^{+}$(see ESI $\dagger$ ). Notably, the synthesis of $\mathrm{MoS}_{2} / \mathrm{NG}_{\mathrm{g}-\mathrm{C}_{3} \mathrm{~N}_{4}}$ can be readily scaled up via our approach (Fig. $\mathrm{S} 1 \dagger$ ).

As indicated by the X-ray diffraction (XRD) patterns of $\mathrm{MoS}_{2} / \mathrm{NG}_{\mathrm{g}_{-\mathrm{C}} \mathrm{N}_{4}}, \mathrm{MoS}_{2} / \mathrm{G}$ and $\mathrm{MoS}_{2} / \mathrm{NGurea}$ (Fig. 1), all of their diffractions are indexed as the hexagonal phase $\mathrm{MoS}_{2}$ (PDF: 65-1951). Among them, $\mathrm{MoS}_{2} / \mathrm{G}$ and $\mathrm{MoS}_{2} /$ NGurea show broad peaks in the $2 \theta$ range of $8.8-17.8^{\circ}$ with the corresponding $d$-spacings of $0.5-1.0 \mathrm{~nm}$. In contrast, $\mathrm{MoS}_{2} / \mathrm{NG}_{\mathrm{g}_{-} \mathrm{C}_{3} \mathrm{~N}_{4}}$ exhibits a highly crystallized structure with a (002) peak centered at $13.4^{\circ}$ and a $d$-spacing of $0.66 \mathrm{~nm}$, which is slightly larger than $0.62 \mathrm{~nm}$ for bulk $\mathrm{MoS}_{2} \cdot{ }^{49}$ Notably, $\mathrm{MoS}_{3} / \mathrm{g}-\mathrm{C}_{3} \mathrm{~N}_{4}-\mathrm{H}^{+} / \mathrm{GO}$ as the precursor of $\mathrm{MoS}_{2} / \mathrm{NG}_{\mathrm{g}^{-} \mathrm{C}_{3} \mathrm{~N}_{4}}$ shows two wide peaks at $14.5^{\circ}$ and $42^{\circ}$ for amorphous $\mathrm{MoS}_{3},{ }^{50,52}$ and a peak at $27.8^{\circ}$ for (002) stacking of $\mathrm{CN}$-conjugated layers from $\mathrm{g}-\mathrm{C}_{3} \mathrm{~N}_{4}-\mathrm{H}^{+} \cdot{ }^{46-48}$ However, no characteristic peaks of $\mathrm{g}-\mathrm{C}_{3} \mathrm{~N}_{4}-\mathrm{H}^{+}$are observed for $\mathrm{MoS}_{2} / \mathrm{NG}_{\mathrm{g}-\mathrm{C}_{3} \mathrm{~N}_{4}}$, implying that $\mathrm{g}-\mathrm{C}_{3} \mathrm{~N}_{4}-\mathrm{H}^{+}$in $\mathrm{MoS}_{3} / \mathrm{g}-\mathrm{C}_{3} \mathrm{~N}_{4}-\mathrm{H}^{+} /$ GO has been decomposed during the thermal treatment.

The morphologies of $\mathrm{g}-\mathrm{C}_{3} \mathrm{~N}_{4}-\mathrm{H}^{+} / \mathrm{GO}, \mathrm{MoS}_{3} / \mathrm{g}-\mathrm{C}_{3} \mathrm{~N}_{4}-\mathrm{H}^{+} / \mathrm{GO}$ and $\mathrm{MoS}_{2} / \mathrm{NG}_{\mathrm{g}-\mathrm{C}_{3} \mathrm{~N}_{4}}$ were investigated by scanning electron microscopy equipped with energy dispersive X-ray analysis (SEM/EDX), transmission electron microscopy (TEM) and atomic force microscopy (AFM). As shown in Fig. 2 a and $\mathrm{S} 3, \dagger$

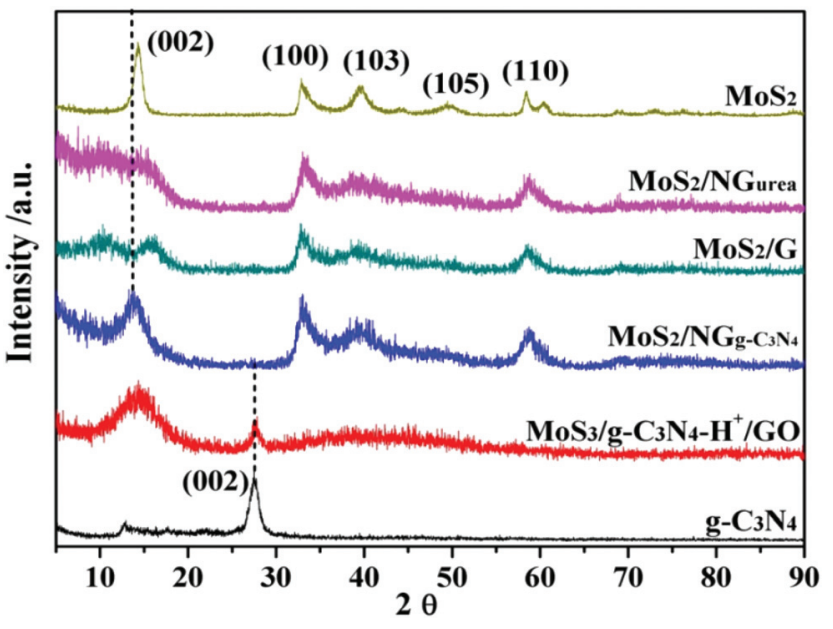

Fig. 1 XRD patterns of $\mathrm{g}-\mathrm{C}_{3} \mathrm{~N}_{4}, \mathrm{MoS}_{3} / \mathrm{g}-\mathrm{C}_{3} \mathrm{~N}_{4}-\mathrm{H}^{+} / \mathrm{GO}, \mathrm{MoS}_{2} / \mathrm{NG}_{\mathrm{g}-\mathrm{C}_{3} \mathrm{~N}_{4^{\prime}}}$ $\mathrm{MoS}_{2} / \mathrm{G}, \mathrm{MoS}_{2} /$ NGurea and bare $\mathrm{MoS}_{2}$.
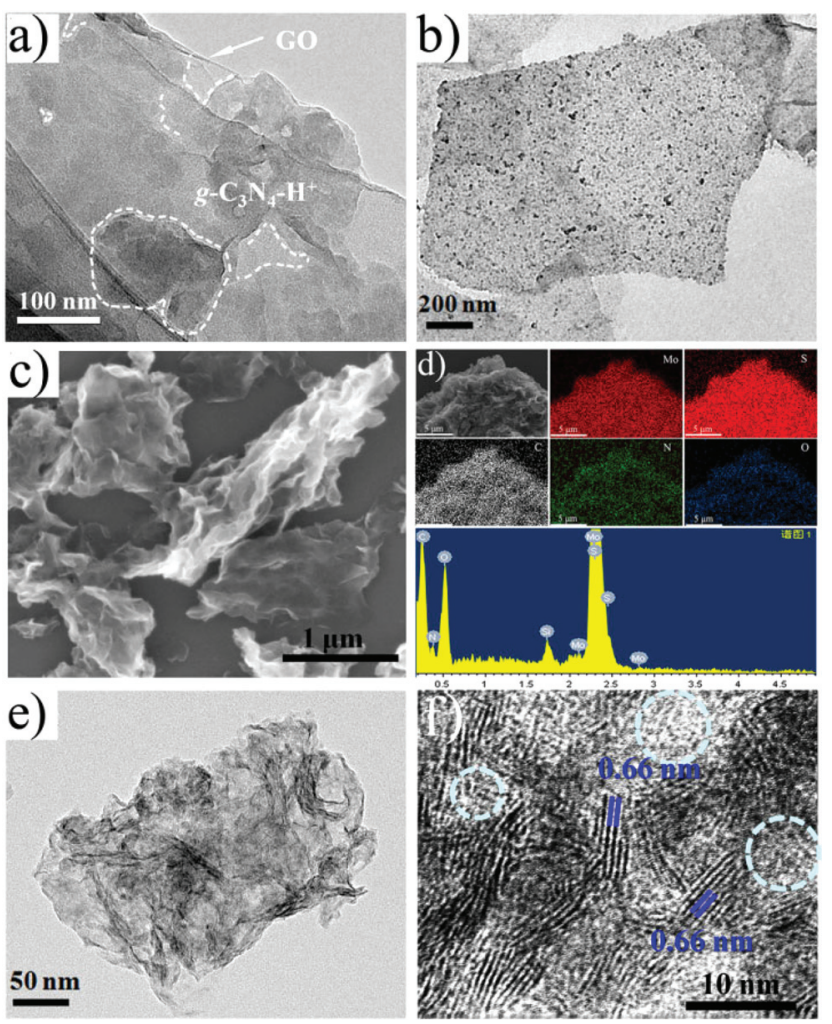

Fig. 2 TEM images of (a) $\mathrm{g}-\mathrm{C}_{3} \mathrm{~N}_{4}-\mathrm{H}^{+} / \mathrm{GO}$; (b) $\mathrm{MoS}_{3} / \mathrm{g}-\mathrm{C}_{3} \mathrm{~N}_{4}-\mathrm{H}^{+} / \mathrm{GO}$; (c) SEM image; (d) EDX with elemental mapping; (e) TEM; and (f) HRTEM images of $\mathrm{MoS}_{2} / \mathrm{NG}_{\mathrm{g}-\mathrm{C}_{3} \mathrm{~N}_{4}}$

g- $\mathrm{C}_{3} \mathrm{~N}_{4}-\mathrm{H}^{+} / \mathrm{GO}$ exhibits a $2 \mathrm{D}$ sheet-like structure with $\mathrm{g}-\mathrm{C}_{3} \mathrm{~N}_{4}-$ $\mathrm{H}^{+}$nanosheets attached on the surface of GO. Such assembly behavior should be driven by the electrostatic attraction between the negatively charged GO and the positively charged $\mathrm{g}-\mathrm{C}_{3} \mathrm{~N}_{4}-\mathrm{H}^{+}$(in aqueous solution, Zeta potential: $-33 \mathrm{mV}$ for $0.25 \mathrm{mg} \mathrm{L}^{-1} \mathrm{GO} ;+10 \mathrm{mV}$ for $0.5 \mathrm{mg} \mathrm{L}^{-1} \mathrm{~g}-\mathrm{C}_{3} \mathrm{~N}_{4}-\mathrm{H}^{+}$) (Fig. $\mathrm{S} 2 \dagger$ ), along with $\pi-\pi$ interactions between their analogous aromatic 

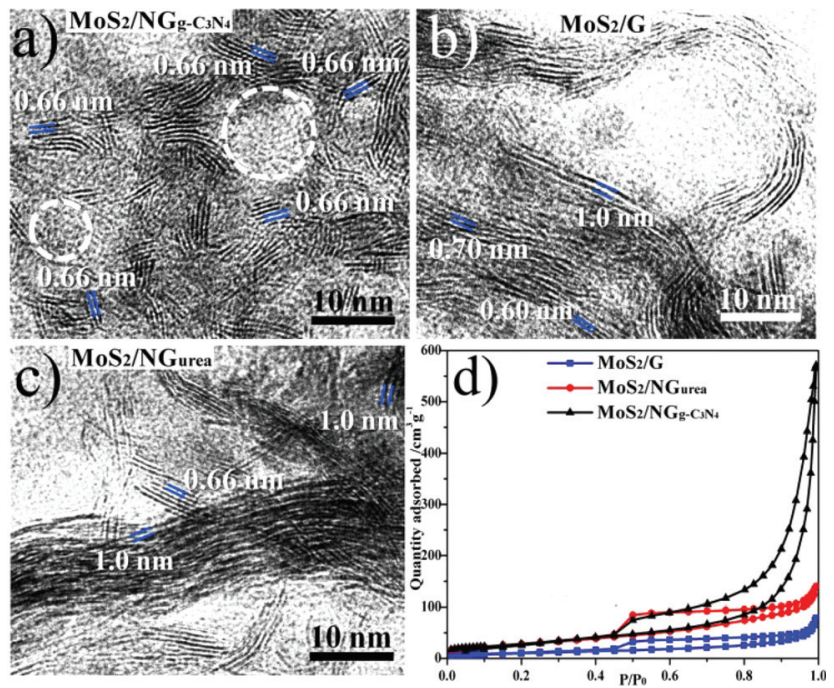

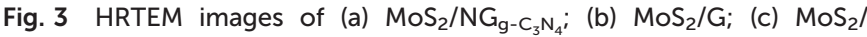
NGurea; (d) nitrogen adsorption-desorption isotherms of $\mathrm{MoS}_{2} /$ $\mathrm{NG}_{\mathrm{g}-\mathrm{C}_{3} \mathrm{~N}_{4^{\prime}}} \mathrm{MoS}_{2} / \mathrm{G}$ and $\mathrm{MoS}_{2} / \mathrm{NGurea}$.

frameworks. AFM study further shows thicknesses of 0.96 and 23-34 nm for GO and $g-\mathrm{C}_{3} \mathrm{~N}_{4}-\mathrm{H}^{+} / \mathrm{GO}$, respectively (Fig. $\mathrm{S} 4 \dagger$ ), verifying that $\mathrm{g}-\mathrm{C}_{3} \mathrm{~N}_{4}-\mathrm{H}^{+}$nanosheets are successfully decorated on the surface of GO. TEM images manifest that $\mathrm{MoS}_{3}$ nanoparticles with diameters of around $5 \mathrm{~nm}$ are homogeneously decorated on $\mathrm{MoS}_{3} / \mathrm{g}-\mathrm{C}_{3} \mathrm{~N}_{4}-\mathrm{H}^{+} / \mathrm{GO}$ (Fig. $2 \mathrm{~b}$ and $\mathrm{S} 5 \dagger$ ). After pyrolysis, $\mathrm{MoS}_{2} / \mathrm{NG}_{\mathrm{g}-\mathrm{C}_{3} \mathrm{~N}_{4}}$ is featured with a flexible $2 \mathrm{D}$ structure inherited from the morphology of $\mathrm{MoS}_{3} / \mathrm{g}-\mathrm{C}_{3} \mathrm{~N}_{4}-\mathrm{H}^{+} / \mathrm{GO}$ (Fig. 2c, 2e, S6 and S7 $\uparrow$ ). EDX and elemental mapping images further disclose that Mo, S, N, C and O elements are homogeneously distributed on $\mathrm{MoS}_{2} / \mathrm{NG}_{\mathrm{g}-\mathrm{C}_{3} \mathrm{~N}_{4}}$ nanosheets (Fig. 2d). High-resolution TEM (HRTEM) images of $\mathrm{MoS}_{2} / \mathrm{NG}_{\mathrm{g}-\mathrm{C}_{3} \mathrm{~N}_{4}}$ reveal that $\mathrm{MoS}_{2}$ nanoplatelets are vertically aligned on the surface. With lengths less than $10 \mathrm{~nm}$, these nanoplatelets contain few stacked layers (3-10) and a uniform $d$-spacing of $0.66 \mathrm{~nm}$ that is consistent with the XRD result (Fig. 2f, 3a, S8 $\dagger$ and Fig. 1). In contrast, $\mathrm{MoS}_{2} / \mathrm{G}$ and $\mathrm{MoS}_{2} / \mathrm{NGurea}$ only possess $\mathrm{MoS}_{2}$ nanosheets with irregular lateral sizes and broad $d$-spacings (Fig. 3b, 3c, S9 and S10 $†$ ) that verify their poor crystallinities along the (002) stacking direction, which might be due to the restrain of the graphene substrate. ${ }^{34,36,39}$ These results also indicate that g- $\mathrm{C}_{3} \mathrm{~N}_{4}-\mathrm{H}^{+}$in the combined $\mathrm{MoS}_{3} / \mathrm{g}-\mathrm{C}_{3} \mathrm{~N}_{4}-\mathrm{H}^{+} / \mathrm{GO}$ precursor can assist the formation of small and highly crystallized $\mathrm{MoS}_{2}$ on graphene during the thermal pyrolysis.

Meso-scaled pores are observed among $\mathrm{MoS}_{2}$ nanoplatelets on $\mathrm{MoS}_{2} / \mathrm{NG}_{\mathrm{g}-\mathrm{C}_{3} \mathrm{~N}_{4}}$ (Fig. 2f, 3a, S8 $\dagger$ ), thereby the porosity was examined by nitrogen physisorption measurement. The adsorption-desorption isotherm of $\mathrm{MoS}_{2} / \mathrm{NG}_{\mathrm{g}-\mathrm{C}_{3} \mathrm{~N}_{4}}$ exhibits a type IV adsorption branch with a $\mathrm{H} 3$ hysteresis loop, which is characteristic of the mesoporous structure (Fig. 3d). Calculated by the DFT method, the pore size distribution of $\mathrm{MoS}_{2} / \mathrm{NG}_{\mathrm{g}-\mathrm{C}_{3} \mathrm{~N}_{4}}$ is in the range of $4-30 \mathrm{~nm}$ (Fig. S12 $\dagger$ ). The corresponding Brunauer-Emmett-Teller (BET) surface area and the total pore volume are calculated to be $109 \mathrm{~m}^{2} \mathrm{~g}^{-1}$ and $0.883 \mathrm{~cm}^{3} \mathrm{~g}^{-1}$, respectively, which are much higher than those of $\mathrm{MoS}_{2} / \mathrm{G}\left(39 \mathrm{~m}^{2} \mathrm{~g}^{-1}\right.$ and $\left.0.1267 \mathrm{~cm}^{3} \mathrm{~g}^{-1}\right), \mathrm{MoS}_{2} / \mathrm{NGurea}$ $\left(100 \mathrm{~m}^{2} \mathrm{~g}^{-1}\right.$ and $\left.0.1267 \mathrm{~cm}^{3} \mathrm{~g}^{-1}\right)$ and other reported $\mathrm{MoS}_{2}$ based materials (30-90 $\mathrm{m}^{2} \mathrm{~g}^{-1}$ and $\left.0.1-0.44 \mathrm{~m}^{3} \mathrm{~g}^{-1}\right) .^{32,37,40,41}$

Thermogravimetric analysis (TGA) under a $\mathrm{N}_{2}$ atmosphere was conducted to understand the formation of $\mathrm{MoS}_{2} / \mathrm{NG}_{\mathrm{g}-\mathrm{C}_{3} \mathrm{~N}_{4}}$. As shown in Fig. S13, $\uparrow$ pure $\mathrm{MoS}_{3}$ exhibits $c a .18 \mathrm{wt} \%$ loss between 380 and $430{ }^{\circ} \mathrm{C}$, corresponding to the conversion of $\mathrm{MoS}_{3}(\mathrm{vI}) \rightarrow \mathrm{MoS}_{2}(\mathrm{Iv})+\mathrm{S} .^{50,52}$ Without the presence of $\mathrm{MoS}_{3}$, the decomposition of $\mathrm{g}-\mathrm{C}_{3} \mathrm{~N}_{4}-\mathrm{H}^{+}$in $\mathrm{g}-\mathrm{C}_{3} \mathrm{~N}_{4}-\mathrm{H}^{+} / \mathrm{GO}$ occurs at $600-750{ }^{\circ} \mathrm{C}$, which is in accordance with reported results for $\mathrm{g}^{-} \mathrm{C}_{3} \mathrm{~N}_{4} \cdot{ }^{27,51}$ Strikingly, the tri-constituent composite of $\mathrm{MoS}_{3} /$ $\mathrm{g}-\mathrm{C}_{3} \mathrm{~N}_{4}-\mathrm{H}^{+} / \mathrm{GO}$ undergoes substantial weight losses at low temperatures of $350-400{ }^{\circ} \mathrm{C}$ and $500-580{ }^{\circ} \mathrm{C}$, assigned to the $\mathrm{MoS}_{3}$ pyrolysis and g- $\mathrm{C}_{3} \mathrm{~N}_{4}-\mathrm{H}^{+}$decomposition, respectively. This result suggests that there are synergistic interactions between molybdenum sulfides $\left(\mathrm{MoS}_{3} / \mathrm{MoS}_{2}\right.$ ) and $\mathrm{g}_{-} \mathrm{C}_{3} \mathrm{~N}_{4}-\mathrm{H}^{+}$during the thermal treatment that promotes the decompositions of both $\mathrm{MoS}_{3}$ and $\mathrm{g}-\mathrm{C}_{3} \mathrm{~N}_{4}-\mathrm{H}^{+}{ }^{52,53}$ Upon treatment of $\mathrm{MoS}_{3} / \mathrm{g}-\mathrm{C}_{3} \mathrm{~N}_{4}-\mathrm{H}^{+} /$ GO at $400{ }^{\circ} \mathrm{C}$ in $\mathrm{N}_{2}$ for $3 \mathrm{~h}$, the coexistence of $\mathrm{MoS}_{2}$ and g- $\mathrm{C}_{3} \mathrm{~N}_{4}$ can be observed in the resulting material (Fig. S14 $\dagger$ ), while, the absence of $\mathrm{g}-\mathrm{C}_{3} \mathrm{~N}_{4}-\mathrm{H}^{+}$features in XRD and Fourier Transform Infrared (FTIR) spectra of $\mathrm{MoS}_{2} / \mathrm{NG}_{\mathrm{g}-\mathrm{C}_{3} \mathrm{~N}_{4}}$ (Fig. 1 and S15 $\dagger$ ) demonstrates the complete decomposition of $\mathrm{g}-\mathrm{C}_{3} \mathrm{~N}_{4}-\mathrm{H}^{+}$in $\mathrm{MoS}_{3} / \mathrm{g}-\mathrm{C}_{3} \mathrm{~N}_{4}-\mathrm{H}^{+} / \mathrm{GO}$ after treated at $550{ }^{\circ} \mathrm{C}$ in $\mathrm{N}_{2}$ for $3 \mathrm{~h}$. During the g- $\mathrm{C}_{3} \mathrm{~N}_{4}-\mathrm{H}^{+}$decomposition, massive gas containing cyano fragments $\left(\text { e.g. } \mathrm{C}_{2} \mathrm{~N}_{2}{ }^{+}, \mathrm{C}_{3} \mathrm{~N}_{2}{ }^{+} \text {, and } \mathrm{C}_{3} \mathrm{~N}_{3}^{+}\right)^{54}$ might be generated from the surface of graphene, which can not only control the growth of $\mathrm{MoS}_{2}$ from $\mathrm{MoS}_{3}$ pyrolysis into small size nanocrystals, but also serve as the nitrogen-rich source to dope graphene with $\mathrm{N}$ at a mild temperature of $550{ }^{\circ} \mathrm{C}$. During the formation of $\mathrm{MoS}_{2}$, the N-enriched graphene substrate can disturb the growth of layered $\mathrm{MoS}_{2}$ crystals, especially in the (002) plane. ${ }^{11,34}$ As a result, the nanocrystals of $\mathrm{MoS}_{2}$ are vertically grown on the surface of graphene. The weight percentage of $\mathrm{MoS}_{2}$ in the resulting $\mathrm{MoS}_{2} / \mathrm{NG}_{\mathrm{g}-\mathrm{C}_{3} \mathrm{~N}_{4}}$ is $c a .70 \mathrm{wt} \%$, based on the TGA under air (Fig. S16 $\dagger$ ).

X-ray photoelectron spectroscopy (XPS) was applied to analyze the chemical states of the elements in $\mathrm{MoS}_{2} / \mathrm{NG}_{\mathrm{g}-\mathrm{C}_{3} \mathrm{~N}_{4}}$, $\mathrm{MoS}_{2} / \mathrm{G}$, and $\mathrm{MoS}_{2} / \mathrm{NGurea,}$ respectively. For $\mathrm{MoS}_{2} / \mathrm{NG}_{\mathrm{g}-\mathrm{C}_{3} \mathrm{~N}_{4}}$, the $\mathrm{N}$ content in graphene is about 13 at\%, which ranks at the top of the reported $\mathrm{N}$-doped graphenes (0.2-10 at\%) (Fig. S18, Table S1†). ${ }^{7-28}$ High-resolution $\mathrm{N}$ 1s spectra further disclose that three $\mathrm{N}$ configurations with $30 \%$ graphitic $\mathrm{N}(401.6 \mathrm{eV})$, $55 \%$ pyridinic $\mathrm{N}(398.4 \mathrm{eV})$ and $15 \%$ pyrrolic $\mathrm{N}(400 \mathrm{eV})$ are presented in the $\mathrm{N}$-enriched graphene (Fig. 4a). In contrast, with a very high feed ratio of urea (see ESI $\dagger$ ), $\mathrm{MoS}_{2} / \mathrm{NGurea}$ obtained at $550{ }^{\circ} \mathrm{C}$ possesses 12 at $\% \mathrm{~N}$, while there are only $5 \%$ graphitic $\mathrm{N}$ along with $76 \%$ pyridinic $\mathrm{N}$ and $19 \%$ pyrrolic $\mathrm{N}$ (Fig. 4c, S19†). In general, the formation of graphitic $\mathrm{N}$ inside the graphene framework is much more difficult than introducing pyridinic and pyrrolic $\mathrm{N}$ atoms on the edges/ defects. High temperature treatment $\left(700-1100{ }^{\circ} \mathrm{C}\right)$ is usually required to improve the amount of graphitic $\mathrm{N},{ }^{7,9,22,25,26,28}$ which nevertheless will lead to massive loss of the total nitrogen content (Table S1†). In our work, the substantial for- 

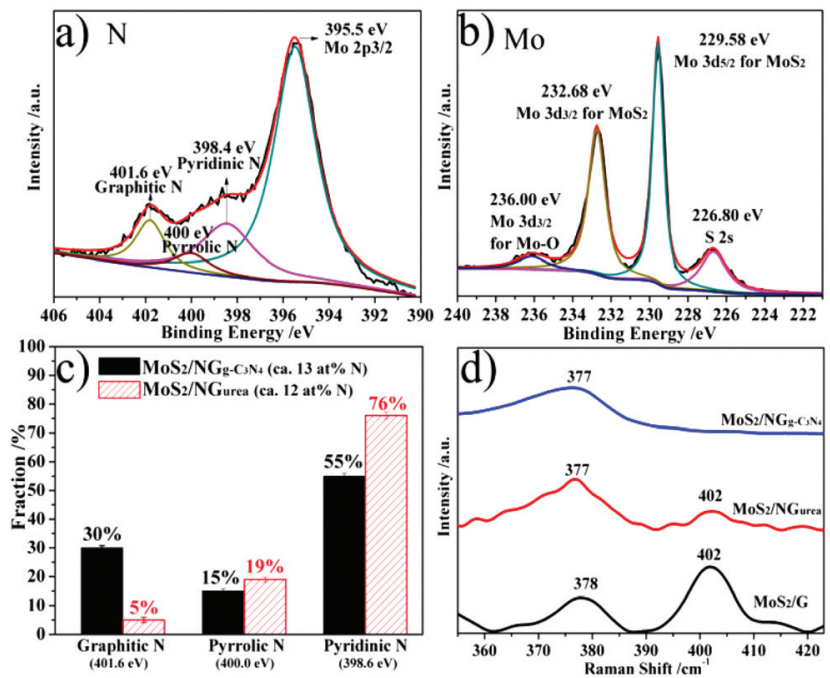

Fig. 4 Core-level XPS spectra of (a) N 1s and Mo 2p; (b) Mo 3d and S 2s

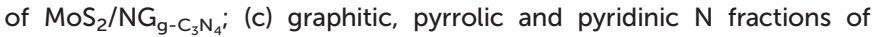

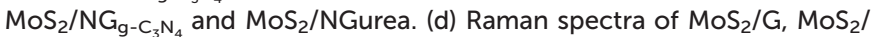

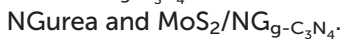

mation of graphitic $\mathrm{N}$ in $\mathrm{MoS}_{2} / \mathrm{NG}_{\mathrm{g}-\mathrm{C}_{3} \mathrm{~N}_{4}}$ at $550{ }^{\circ} \mathrm{C}$ can be stemmed from the complete decomposition of $\mathrm{g}-\mathrm{C}_{3} \mathrm{~N}_{4}-\mathrm{H}^{+}$ attached on GO promoted by molybdenum sulfide. Graphitic $\mathrm{N}$ has proven to favor the electron transfer from $\mathrm{N}$ to the adjacent $\mathrm{C}$ atoms and reduce the adsorption energy of lithium, which are desired for LIBs applications. ${ }^{8,9}$ In addition, Mo $3 \mathrm{~d}_{5 / 2}$ and $3 \mathrm{~d}_{3 / 2}$ peaks appearing at 229.58 and $232.68 \mathrm{eV}$ for $\mathrm{MoS}_{2} /$ $\mathrm{NG}_{\mathrm{g}^{-} \mathrm{C}_{3} \mathrm{~N}_{4}}$ are lower than 229.64 and $232.83 \mathrm{eV}$ for $\mathrm{MoS}_{2} / \mathrm{G}$ (Fig. 4b, S20 ${ }^{\dagger}$ ), indicating that there is an electron delocalization from the N-enriched graphene to the coupled $\mathrm{MoS}_{2}$.

Raman characterizations further studied the coupling effect between $\mathrm{MoS}_{2}$ and graphene in $\mathrm{MoS}_{2} / \mathrm{G}, \mathrm{MoS}_{2} /$ NGurea and $\mathrm{MoS}_{2} / \mathrm{NG}_{\mathrm{g}-\mathrm{C}_{3} \mathrm{~N}_{4}}$. As shown in Fig. 4d, two peaks at 378 and $402 \mathrm{~cm}^{-1}$ for $\mathrm{MoS}_{2} / \mathrm{G}$ are assigned to the in-plane $\mathrm{E}_{2 \mathrm{~g}}^{1}$ and outof-plane $\mathrm{A}_{1 \mathrm{~g}}$ modes of hexagonal $\mathrm{MoS}_{2}$. However, $\mathrm{MoS}_{2} /$ NGurea and $\mathrm{MoS}_{2} / \mathrm{NG}_{\mathrm{g}-\mathrm{C}_{3} \mathrm{~N}_{4}}$ only possess strong signals for $\mathrm{E}_{2 \mathrm{~g}}^{1}$ mode. The peak of $\mathrm{A}_{1 \mathrm{~g}}$ mode is weakened for $\mathrm{MoS}_{2} / \mathrm{NGurea}$ and even disappeared for $\mathrm{MoS}_{2} / \mathrm{NG}_{\mathrm{g}-\mathrm{C}_{3} \mathrm{~N}_{4}}$. It has been evidenced that the signal of the $\mathrm{A}_{1 \mathrm{~g}}$ mode for $\mathrm{MoS}_{2}$ can be significantly softened and broadened by external factors such as substrates or electron doping. ${ }^{55,56}$ The Raman results demonstrate the enormously enhanced coupling between $\mathrm{MoS}_{2}$ and the $\mathrm{N}$-enriched graphene in $\mathrm{MoS}_{2} / \mathrm{NG}_{\mathrm{g}-\mathrm{C}_{3} \mathrm{~N}_{4}}$.

The electrochemical performances of $\mathrm{MoS}_{2} / \mathrm{NG}_{\mathrm{g}-\mathrm{C}_{3} \mathrm{~N}_{4}}$, $\mathrm{MoS}_{2} / \mathrm{NGurea}$ and $\mathrm{MoS}_{2} / \mathrm{G}$ as anodes in LIBs were first investigated by cyclic voltammogram (CV). As shown in Fig. 5a, in the first cathodic scan, the $1.01 \mathrm{~V}$ peak is assigned to the $\mathrm{Li}^{+}$intercalation into $\mathrm{MoS}_{2}$ layers for forming $\mathrm{Li}_{x} \mathrm{MoS}_{2},{ }^{34,39} 0.36 \mathrm{~V}$ peak is attributed to the reduction of $\mathrm{Li}_{x} \mathrm{MoS}_{2}$ to $\mathrm{Mo}$ and $\mathrm{Li}_{2} \mathrm{~S}$. $^{34,37,39}$ In the anodic scans, the peaks around 1.70 and $2.28 \mathrm{~V}$ can be associated with the conversions of Mo to $\mathrm{MoS}_{2}$ along with $\mathrm{Li}_{2} \mathrm{~S}$ to polysulfide, respectively. ${ }^{34,38,39}$ In the subsequent cathodic scans, three reductive peaks appearing at 1.95, 1.25 and $0.40 \mathrm{~V}$ are attributed to $2 \mathrm{Li}^{+}+\mathrm{S}+2 \mathrm{e}^{-} \rightarrow \mathrm{Li}_{2} \mathrm{~S}, \mathrm{MoS}_{2}+x \mathrm{Li}^{+}+\mathrm{xe}^{-} \rightarrow$
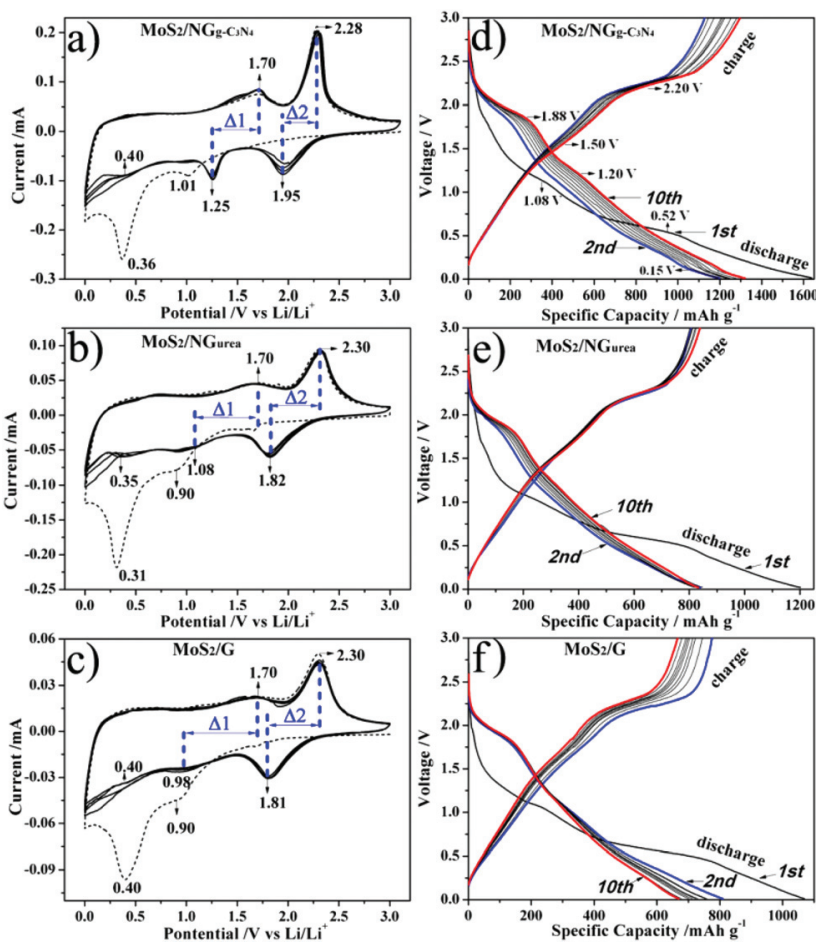

Fig. $5 \mathrm{CV}$ curves at a scanning rate of $0.1 \mathrm{mV} \mathrm{s}^{-1}$ of the first 5 cycles

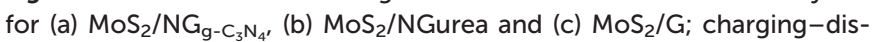
charging curves at $0.1 \mathrm{~A} \mathrm{~g}^{-1}$ of the first 10 cycles for (d) $\mathrm{MoS}_{2} / \mathrm{NG}_{\mathrm{g}-\mathrm{C}_{3} \mathrm{~N}_{4^{\prime}}}$ (e) $\mathrm{MoS}_{2} /$ NGurea and (f) $\mathrm{MoS}_{2} / \mathrm{G}$.

$\mathrm{Li}_{x} \mathrm{MoS}_{2}$, and $\mathrm{Li}_{x} \mathrm{MoS}_{2}+(4-x) \mathrm{Li}^{+}+(4-x) \mathrm{e}^{-} \rightarrow 2 \mathrm{Li}_{2} \mathrm{~S}+\mathrm{Mo}$, respectively. ${ }^{34,37}$ It is notable that the peak at $1.25 \mathrm{~V}$ of $\mathrm{MoS}_{2} /$ $\mathrm{NG}_{\mathrm{g}^{-} \mathrm{C}_{3} \mathrm{~N}_{4}}$ for $\mathrm{MoS}_{2}+x \mathrm{Li}^{+}+\mathrm{xe}^{-} \rightarrow \mathrm{Li}_{x} \mathrm{MoS}_{2}$ is much sharper than those of $\mathrm{MoS}_{2} / \mathrm{G}(0.98 \mathrm{~V})$ and $\mathrm{MoS}_{2} / \mathrm{NGurea}(1.08 \mathrm{~V})$. Besides, the potential differences between the pairs of oxidative/reductive peaks measured with $0.45 \mathrm{~V}(\Delta 1)$ and $0.33 \mathrm{~V}$ $(\Delta 2)$ for $\mathrm{MoS}_{2} / \mathrm{NG}_{\mathrm{g}-\mathrm{C}_{3} \mathrm{~N}_{4}}$ are much smaller than those for $\mathrm{MoS}_{2} /$ $\mathrm{G}(0.72,0.49 \mathrm{~V}), \mathrm{MoS}_{2} / \mathrm{NGurea}(0.62,0.48 \mathrm{~V})$ (Fig. $\left.5 \mathrm{a}-\mathrm{c}\right)$ or the reported $\mathrm{MoS}_{2} / \mathrm{N}$-graphene using ammonia as the nitrogen source, ${ }^{11}$ demonstrating that $\mathrm{MoS}_{2} / \mathrm{NG}_{\mathrm{g}_{-} \mathrm{C}_{3} \mathrm{~N}_{4}}$ possesses the best reversibility of the lithiation/delithiation conversions and the lowest internal diffusion resistance. ${ }^{57}$

$\mathrm{MoS}_{2} / \mathrm{NG}_{\mathrm{g}-\mathrm{C}_{3} \mathrm{~N}_{4}}, \mathrm{MoS}_{2} / \mathrm{G}$ and $\mathrm{MoS}_{2} / \mathrm{NGurea}$ were further evaluated by galvanostatic charge-discharge cycling at $0.1 \mathrm{~A} \mathrm{~g}^{-1}$. As shown in Fig. 5d, the plateaus on the charge/discharge curves of $\mathrm{MoS}_{2} / \mathrm{NG}_{\mathrm{g}-\mathrm{C}_{3} \mathrm{~N}_{4}}$ are in good agreement with the conversion peaks on its CV (Fig. 5a). Different from $\mathrm{MoS}_{2} / \mathrm{G}$ and $\mathrm{MoS}_{2} / \mathrm{NGurea}, \mathrm{MoS}_{2} / \mathrm{NG}_{\mathrm{g}-\mathrm{C}_{3} \mathrm{~N}_{4}}$ shows right shifted charge/ discharge curves with increasing capacities along the 2-10 cycles in the whole voltage range of $0.01-3 \mathrm{~V}$ (Fig. $5 \mathrm{~d}-\mathrm{f}$ ), presenting its increasing reversibility of the lithiation/delithiation during the initial cycles. This result might be associated with the mesoporous surface of $\mathrm{MoS}_{2} / \mathrm{NG}_{\mathrm{g}-\mathrm{C}_{3} \mathrm{~N}_{4}}$ that allows an efficient electrode-electrolyte contact and an effective activation of the $\mathrm{N}$ defects for Li storage. ${ }^{11,12}$ As shown in Fig. 6a, $\mathrm{MoS}_{2} /$ $\mathrm{NG}_{\mathrm{g}-\mathrm{C}_{3} \mathrm{~N}_{4}}$ exhibits first and second discharge capacities of 1728 and $1200 \mathrm{~mA} \mathrm{~h} \mathrm{~g}^{-1}$, which increases to $1450 \mathrm{~mA} \mathrm{~h} \mathrm{~g}^{-1}$ with as 

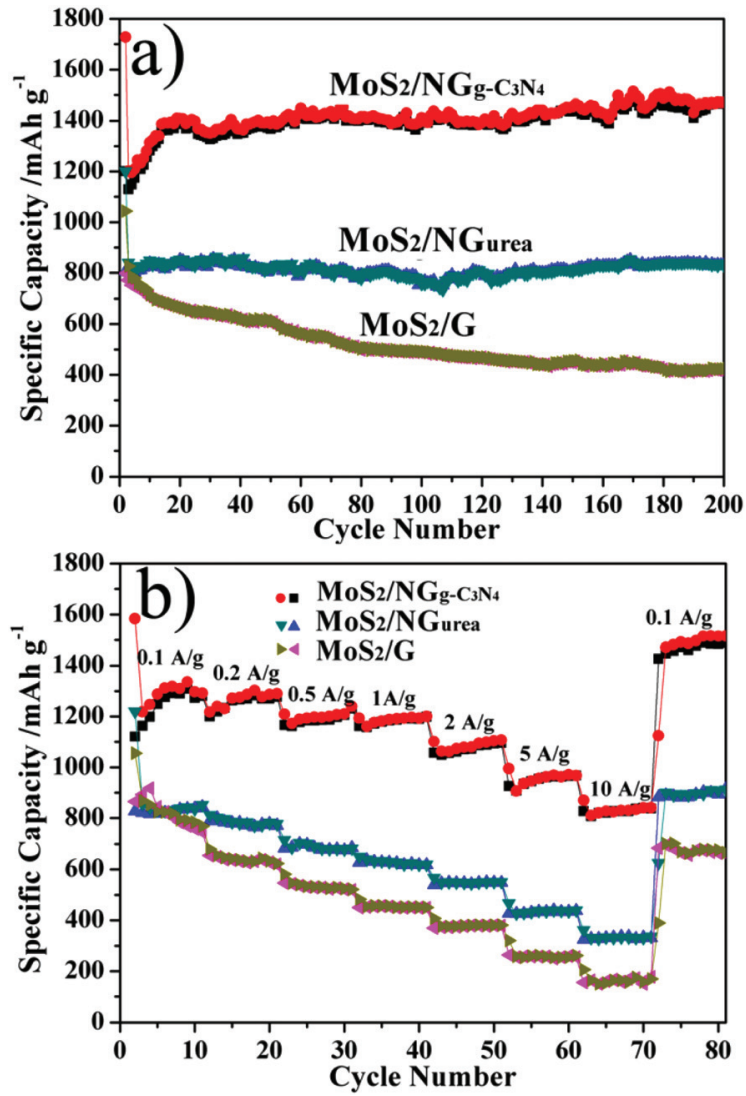

Fig. 6 (a) Variation of charge/discharge specific capacities versus cycle

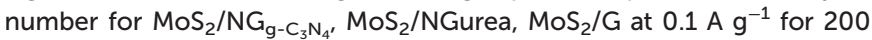
cycles; (b) specific capacities versus cycle number for $\mathrm{MoS}_{2} / \mathrm{NG}_{\mathrm{g}-\mathrm{C}_{3} \mathrm{~N}_{4^{\prime}}}$ $\mathrm{MoS}_{2} /$ NGurea, $\mathrm{MoS}_{2} / \mathrm{G}$ at $0.1,0.2,0.5,1,2,5,10 \mathrm{~A} \mathrm{~g}^{-1}$.

high as $84 \%$ retention of the first discharge capacity and then retains for 200 cycles. In contrast, $\mathrm{MoS}_{2} / \mathrm{G}$ delivers first and second discharge capacities of 1043 and $826 \mathrm{~mA} \mathrm{~h} \mathrm{~g}^{-1}$, which decreases to $405 \mathrm{~mA} \mathrm{~h} \mathrm{~g}{ }^{-1}$ after 200 cycles with only $39 \%$ of the first discharge capacity. Although the prepared $\mathrm{MoS}_{2} /$ NGurea also shows good stability, the delivered capacities (800 $\mathrm{mA} \mathrm{h} \mathrm{g}^{-1}$ ) with $67 \%$ of the first discharge capacity (1200 $\mathrm{mA} \mathrm{h} \mathrm{g}{ }^{-1}$ ) are much lower than those of $\mathrm{MoS}_{2} / \mathrm{NG}_{\mathrm{g}^{-} \mathrm{C}_{3} \mathrm{~N}_{4}}$. It is notable that the high surface area of $\mathrm{MoS}_{2} / \mathrm{NG}_{\mathrm{g}-\mathrm{C}_{3} \mathrm{~N}_{4}}$ has not increased its side reaction with an electrolyte as other reported materials with a large capacity loss ${ }^{58}$ which should be due to the least irreversible $\mathrm{Li}^{+}$consumption by stable SEI formation on the surface of the strong coupled nanosheet.

Rate performances of $\mathrm{MoS}_{2} / \mathrm{NG}_{\mathrm{g}-\mathrm{C}_{3} \mathrm{~N}_{4}}, \mathrm{MoS}_{2} / \mathrm{G}$ and $\mathrm{MoS}_{2} /$ NGurea were examined at various current densities in the range of $0.1-10 \mathrm{~A} \mathrm{~g}^{-1}$ (Fig. 6b). Reversible capacities of around 1220-1310, 1300, 1230, 1200, 1100, $960 \mathrm{~mA} \mathrm{~h} \mathrm{~g}^{-1}$ are achieved for $\mathrm{MoS}_{2} / \mathrm{NG}_{\mathrm{g}_{-\mathrm{C}_{3} \mathrm{~N}_{4}}}$ at $0.1,0.2,0.5,1,2$ and $5 \mathrm{~A} \mathrm{~g}^{-1}$, respectively. Remarkably, as high as $92 \%$ of the $1310 \mathrm{~mA} \mathrm{~h} \mathrm{~g}^{-1}$ at $0.1 \mathrm{~A} \mathrm{~g}^{-1}$ is retained at $1 \mathrm{~A} \mathrm{~g}^{-1}$ with $1200 \mathrm{~mA} \mathrm{~h} \mathrm{~g}^{-1}$. The charge/discharge process can be even completed within $4 \mathrm{~min}$ at an ultrahigh current density of $10 \mathrm{~A} \mathrm{~g}^{-1}$ with a remarkable capacity of $830 \mathrm{~mA} \mathrm{~h} \mathrm{~g}{ }^{-1}$, which is more than twice the theoretical capacity of graphite. Upon resetting the current density to 0.1 $\mathrm{A} \mathrm{g}^{-1}$, a reversible capacity of around $1460 \mathrm{~mA} \mathrm{~h} \mathrm{~g}{ }^{-1}$ is restored that even surpasses the capacities during the initial 10 cycles, which should take into account the activation process. In contrast, both $\mathrm{MoS}_{2} / \mathrm{G}$ and $\mathrm{MoS}_{2} /$ NGurea deliver inferior capacities of 840, 620, $330 \mathrm{~mA} \mathrm{~h} \mathrm{~g}^{-1}$ and 820, 500, $160 \mathrm{~mA} \mathrm{~h} \mathrm{~g}^{-1}$ at 0.1, 1, $10 \mathrm{~A} \mathrm{~g}^{-1}$, respectively. As summarized in Table $\mathrm{S} 2, \uparrow$ the exceptional capacity and rate capability of $\mathrm{MoS}_{2} / \mathrm{NG}_{\mathrm{g}-\mathrm{C}_{3} \mathrm{~N}_{4}}$ also outstrip those of the previously reported $\mathrm{MoS}_{2} / \mathrm{C}$ (369-986 $\mathrm{mA} \mathrm{h}$ $\mathrm{g}^{-1}$ at $\left.1 \mathrm{~A} \mathrm{~g}^{-1}\right),{ }^{40-43} \mathrm{MoS}_{2} /$ graphene (500-1040 $\mathrm{mA} \mathrm{h} \mathrm{g}^{-1}$ at $1 \mathrm{~A}$ $\mathrm{g}^{-1}$ ), ${ }^{30-39} \mathrm{MoS}_{2} / \mathrm{N}$-graphene (850 $\mathrm{mA} \mathrm{h} \mathrm{g}{ }^{-1}$ at $1 \mathrm{~A} \mathrm{~g}^{-1}$ ), ${ }^{11}$ other $\mathrm{N}$-graphene based composites with $\mathrm{SnO}_{2}, \mathrm{Fe}_{3} \mathrm{O}_{4}$ (683-994 mA $\mathrm{h} \mathrm{g}^{-1}$ at $\left.1 \mathrm{~A} \mathrm{~g}^{-1}\right),{ }^{10,12,13}$ and tubular $\mathrm{TiO}_{2}\left(114,164 \mathrm{~mA} \mathrm{~h} \mathrm{~g}{ }^{-1}\right.$ at $\left.5 \mathrm{~A} \mathrm{~g}^{-1}\right){ }^{44,45}$

Kinetic differences of $\mathrm{MoS}_{2} / \mathrm{NG}_{\mathrm{g}-\mathrm{C}_{3} \mathrm{~N}_{4}}, \mathrm{MoS}_{2} / \mathrm{G}$ and $\mathrm{MoS}_{2} /$ NGurea electrodes were investigated by electrochemical impedance spectroscopy (EIS) after 30 cycles. As shown in Fig. 7a, the high-frequency semicircle corresponds to the solid SEI film resistance $\left(R_{\mathrm{f}}\right)$ and the constant phase element (CPE1), the semicircle in the medium-frequency region is assigned to the charge-transfer impedance $\left(R_{\mathrm{ct}}\right)$ and the constant phase element of the electrode-electrolyte interface (CPE2), and $Z_{\mathrm{W}}$ is associated with the Warburg impedance. Obviously, $\mathrm{MoS}_{2}$ / $\mathrm{NG}_{\mathrm{g}-\mathrm{C}_{3} \mathrm{~N}_{4}}$ possesses more depressed semicircles at high frequencies. The SEI film resistance $\left(R_{\mathrm{f}}\right)$ and charge-transfer resistance $\left(R_{\mathrm{ct}}\right)$ for $\mathrm{MoS}_{2} / \mathrm{NG}_{\mathrm{g}-\mathrm{C}_{3} \mathrm{~N}_{4}}$ based on the modified equivalent circuit (Inset of Fig. 7a) are fitted to be 12.3 and $9.2 \Omega$, which are significantly lower than those of $\mathrm{MoS}_{2} / \mathrm{G}(204.8$ and $14.33 \Omega$ ) and $\mathrm{MoS}_{2} / \mathrm{NGurea}$ (70.9 and $27.7 \Omega$ ). These results confirm that the $\mathrm{N}$-enriched graphene substrate in $\mathrm{MoS}_{2} / \mathrm{NG}_{\mathrm{g}^{-} \mathrm{C}_{3} \mathrm{~N}_{4}}$ has distinctively boosted the electronic conductivity of the hybrid. Besides, the strong coupled com-

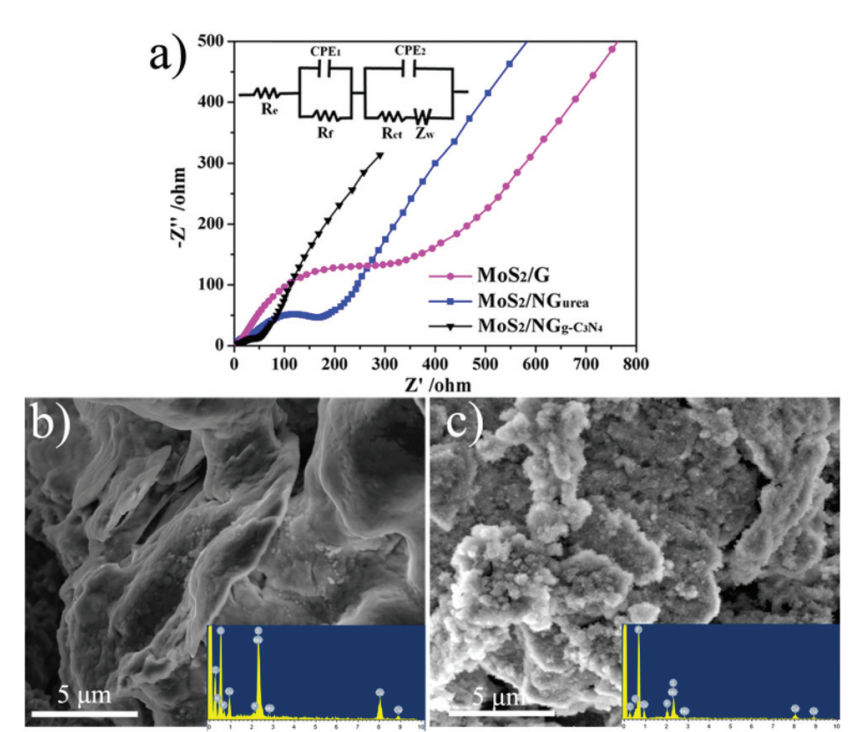

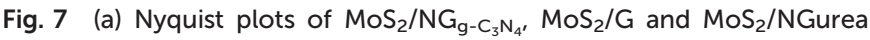
electrodes, the inset is the equivalent circuit model of the studied system; SEM image of the electrodes after 200 cycles for (b) $\mathrm{MoS}_{2} /$

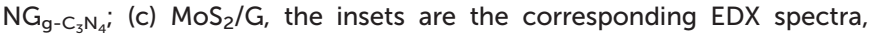
$\mathrm{F}$ and $\mathrm{P}$ elements are from the composition of the SEI layer. 
ponents in $\mathrm{MoS}_{2} / \mathrm{NG}_{\mathrm{g}-\mathrm{C}_{3} \mathrm{~N}_{4}}$ nanosheets should be responsible for stable $\mathrm{Li}^{+}$conductive SEI layer formation (Fig. 7b) with reduced contact resistance, allowing rapid electron transport for high electrochemical performance. ${ }^{58}$

From above, the super lithium storage performance of $\mathrm{MoS}_{2} / \mathrm{NG}_{\mathrm{g}-\mathrm{C}_{3} \mathrm{~N}_{4}}$ can be attributed to the synergistic effects from $\mathrm{MoS}_{2}$ and N-enriched graphene: first, highly crystallized layered $\mathrm{MoS}_{2}$ nanoplatelets vertically exposed on the nanosheets and rich content of $\mathrm{N}$ dopants in the underlying graphene can provide abundant accessible active sites for lithium intercalation and chemical adsorption, ${ }^{9-13,29}$ resulting in the excellent capacities. Second, the high content of $\mathrm{N}$ dopants distributed on defects/edges and inside of graphene obtained from pyrolysis of the assembled precursor $\left(\mathrm{MoS}_{3} /\right.$ $\mathrm{g}^{-} \mathrm{C}_{3} \mathrm{~N}_{4}-\mathrm{H}^{+} / \mathrm{GO}$ ) has significantly enhanced its coupling with $\mathrm{MoS}_{2}$ dispersed on the surface, which renders the ultra-long cycle life by efficiently prohibiting the aggregation or detachment of the active $\mathrm{MoS}_{2}$ on graphene during cycling. As shown in Fig. S21, $\dagger$ Mo species are well dispersed on the nanosheets after 200 charge/discharge cycles of $\mathrm{MoS}_{2} / \mathrm{NG}_{\mathrm{g}-\mathrm{C}_{3} \mathrm{~N}_{4}},{ }^{30}$ whereas, $\mathrm{MoS}_{2} / \mathrm{G}$ suffers from severe aggregations (Fig. 7b and S22 †). Another merit of the strong coupled architecture is the effectively reduced interfacial resistance within the hybrid, along with the $\mathrm{N}$ enriched graphene as the electrical highway, the intrinsic electronic conductivity of the whole hybrid is largely boosted that is beneficial for ultrafast charging/discharging. Additionally, the architecture of mesoporous nanosheets with a high surface area is beneficial for the electrode-electrolyte contact and facilitates ion diffusions.

\section{Conclusions}

In summary, we have developed a facile and efficient strategy to construct a novel 2D hybrid of $\mathrm{MoS}_{2} / \mathrm{NG}_{\mathrm{g}-\mathrm{C}_{3} \mathrm{~N}_{4}}$ by the mild temperature $\left(550{ }^{\circ} \mathrm{C}\right)$ pyrolysis of assembled $\mathrm{MoS}_{3} / \mathrm{g}-\mathrm{C}_{3} \mathrm{~N}_{4}-\mathrm{H}^{+} /$ GO. Benefiting from the architecture of mesoporous nanosheets with highly crystallized $\mathrm{MoS}_{2}$ nanoplatelets strongly coupled on N-enriched graphene, boosted electron/ ion transportation and rich lithium storage sites are achieved. As a result, the $\mathrm{MoS}_{2} / \mathrm{NG}_{\mathrm{g}-\mathrm{C}_{3} \mathrm{~N}_{4}}$ based LIB anode manifests small side reaction with an electrolyte, excellent capacities with long term stability (1450 mA h g${ }^{-1}$ at $0.1 \mathrm{~A} \mathrm{~g}^{-1}$ for 200 cycles) and extraordinary rate capabilities $\left(1200 \mathrm{~mA} \mathrm{~h} \mathrm{~g}^{-1}\right.$ at $1 \mathrm{~A}$ $\mathrm{g}^{-1}, 830 \mathrm{~mA} \mathrm{~h} \mathrm{~g}^{-1}$ at $\left.10 \mathrm{~A} \mathrm{~g}^{-1}\right)$. More importantly, the presented strategy provides a new avenue towards the large-scale production of strongly coupled $\mathrm{N}$-enriched graphene based hybrids for various energy applications including $\mathrm{Na} / \mathrm{Mg}$ batteries, fuel cells, supercapacitors, etc.

\section{Acknowledgements}

This work was financially supported by the 973 Program of China (2012CB933404, 2013CBA01602, 2013CB328804 and 2014CB239701), the Natural Science Foundation of China (61235007, 21174083, 21102091 and 21372155), the Ph.D. Pro- grams Foundation of Ministry of Education of China for Young Scholars (20110073120039), the Program for Professor of Special Appointment (Eastern Scholar), the Natural Science Foundation of Shanghai City (13ZR1421200). We also thank the Instrumental Analysis Center of Shanghai Jiao Tong University for providing some measurements.

\section{Notes and references}

1 P. Poizot, S. Laruelle, S. Grugeon, L. Dupont and J. Tarascon, Nature, 2000, 407, 496.

2 K. Novoselov, A. Geim, S. Morozov, D. Jiang, Y. Zhang, S. Dubonos, I. Grigorieva and A. Firsov, Science, 2004, 306, 666.

3 X. Huang, X. Qi, F. Boey and H. Zhang, Chem. Soc. Rev., 2012, 41, 666.

4 B. Luo, B. Wang, X. Li, Y. Jia, M. Liang and L. Zhi, Adv. Mater., 2012, 24, 3538.

5 Y. Su, S. Li, D. Wu, F. Zhang, H. Liang, P. Gao, C. Cheng and X. Feng, ACS Nano, 2012, 6, 8349.

6 X. Zhu, Y. Zhu, S. Murali, M. D. Stoller and R. S. Ruoff, ACS Nano, 2011, 5, 3333.

7 X. Wang, X. Li, L. Zhang, Y. Yoon, P. K. Weber, H. Wang, J. Guo and H. Dai, Science, 2009, 324, 768.

8 L. Zhao, R. He, K. T. Rim, T. Schiros, K. S. Kim, H. Zhou, C. Gutiérrez, S. P. Chockalingam, C. J. Arguello, L. Pálová, D. Nordlund, M. S. Hybertsen, D. R. Reichman, T. F. Heinz, P. Kim, A. Pinczuk, G. W. Flynn and A. N. Pasupathy, Science, 2011, 333, 999.

9 Y. J. Cho, H. S. Kim, H. Im, Y. Myung, G. B. Jung, C. W. Lee, J. Park, M.-H. Park, J. Cho and H. S. Kang, J. Phys. Chem. C, 2011, 115, 9451.

10 X. Wang, X. Cao, L. Bourgeois, H. Guan, S. Chen, Y. Zhong, D. M. Tang, H. Li, T. Zhai and L. Li, Adv. Funct. Mater., 2012, 22, 2682.

11 K. Chang, D. Geng, X. Li, J. Yang, Y. Tang, M. Cai, R. Li and X. Sun, Adv. Energy Mater., 2013, 3, 839.

12 X. Zhou, L. J. Wan and Y. G. Guo, Adv. Mater., 2013, 25, 2152.

13 Y. Chang, J. Li, B. Wang, H. Luo, H. He, Q. Song and L. Zhi, J. Mater. Chem. A, 2013, 1, 14658.

14 D. Wei, Y. Liu, Y. Wang, H. Zhang, L. Huang and G. Yu, Nano Lett., 2009, 9, 1752.

15 H. M. Jeong, J. W. Lee, W. H. Shin, Y. J. Choi, H. J. Shin, J. K. Kang and J. W. Choi, Nano Lett., 2011, 11, 2472.

16 Y. Wang, Y. Shao, D. W. Matson, J. Li and Y. Lin, ACS Nano, 2010, 4, 1790.

17 L. S. Panchakarla, K. S. Subrahmanyam, S. K. Saha, A. Govindaraj, H. R. Krishnamurthy, U. V. Waghmare and C. N. R. Rao, Adv. Mater., 2009, 21, 4726.

18 D. Deng, X. Pan, L. Yu, Y. Cui, Y. Jiang, J. Qi, W.-X. Li, Q. Fu, X. Ma, Q. Xue, G. Sun and X. Bao, Chem. Mater., 2011, 23, 1188.

19 D. Long, W. Li, L. Ling, J. Miyawaki, I. Mochida and S.-H. Yoon, Langmuir, 2010, 26, 16096. 
20 Z.-S. Wu, S. Yang, Y. Sun, K. Parvez, X. Feng and K. Müllen, J. Am. Chem. Soc., 2012, 134, 9082.

21 Y. Liang, Y. Li, H. Wang, J. Zhou, J. Wang, T. Regier and H. Dai, Nat. Mater., 2011, 10, 780.

22 L. Lai, J. R. Potts, D. Zhan, L. Wang, C. K. Poh, C. Tang, H. Gong, Z. Shen, J. Lin and R. S. Ruoff, Energy Environ. Sci., 2012, 5, 7936.

23 H.-W. Liang, W. Wei, Z.-S. Wu, X. Feng and K. Müllen, J. Am. Chem. Soc., 2013, 135, 16002.

24 G. Wu, K. L. More, C. M. Johnston and P. Zelenay, Science, 2011, 332, 443.

25 Z. Lin, G. Waller, Y. Liu, M. Liu and C.-P. Wong, Adv. Energy Mater., 2012, 2, 884.

26 Z.-H. Sheng, L. Shao, J.-J. Chen, W.-J. Bao, F.-B. Wang and X.-H. Xia, ACS Nano, 2011, 5, 4350.

27 H. R. Byon, J. Suntivich and Y. Shao-Horn, Chem. Mater., 2011, 23, 3421-3428.

28 G. Wu, N. H. Mack, W. Gao, S. Ma, R. Zhong, J. Han, J. K. Baldwin and P. Zelenay, ACS Nano, 2012, 6, 9764.

29 M. Chhowalla, H. S. Shin, G. Eda, L.-J. Li, K. P. Loh and H. Zhang, Nat. Chem., 2013, 5, 263.

30 J. Xiao, X. Wang, X.-Q. Yang, S. Xun, G. Liu, P. K. Koech, J. Liu and J. P. Lemmon, Adv. Funct. Mater., 2011, 21, 2840.

31 Y. Gong, S. Yang, L. Zhan, L. Ma, R. Vajtai and P. M. Ajayan, Adv. Funct. Mater., 2014, 24, 125.

32 V. H. Pham, K.-H. Kim, D.-W. Jung, K. Singh, E.-S. Oh and J. S. Chung, J. Power Sources, 2013, 244, 280.

33 X. Cao, Y. Shi, W. Shi, X. Rui, Q. Yan, J. Kong and H. Zhang, Small, 2013, 9, 3433.

34 K. Chang and W. Chen, ACS Nano, 2011, 5, 4720.

35 K. Chang and W. Chen, Chem. Commun., 2011, 47, 4252.

36 G. Huang, T. Chen, W. Chen, Z. Wang, K. Chang, L. Ma, F. Huang, D. Chen and J. Y. Lee, Small, 2013, 9, 3693.

37 H. Yu, C. Ma, B. Ge, Y. Chen, Z. Xu, C. Zhu, C. Li, Q. Ouyang, P. Gao, J. Li, C. Sun, L. Qi, Y. Wang and F. Li, Chem. - Eur. J., 2013, 19, 5818.

38 K. Zhang, H.-J. Kim, X. Shi, J.-T. Lee, J.-M. Choi, M.-S. Song and J. H. Park, Inorg. Chem., 2013, 52, 9807.

39 Z. Wang, T. Chen, W. Chen, K. Chang, L. Ma, G. Huang, D. Chen and J. Y. Lee, J. Mater. Chem. A, 2013, 1, 2202.
40 S. Ding, J. S. Chen and X. W. Lou, Chem. - Eur. J., 2011, 17, 13142.

41 X. Zhou, L.-J. Wan and Y.-G. Guo, Nanoscale, 2012, 4, 5868.

42 C. Zhu, X. Mu, P. A. van Aken, Y. Yu and J. Maier, Angew. Chem., Int. Ed., 2014, 53, 2152.

43 X. Xu, Z. Fan, X. Yu, S. Ding, D. Yu and X. W. Lou, Adv. Energy Mater, DOI: 10.1002/aenm.201400902.

44 Y. Tang, Y. Zhang, J. Deng, D. Qi, W. R. Leow, J. Wei, S. Yin, Z. Dong, R. Yazami, Z. Chen and X. Chen, Angew. Chem., Int. Ed., 2014, DOI: 10.1002/anie.201406719.

45 Y. Tang, Y. Zhang, J. Deng, J. Wei, H. L. Tam, B. K. Chandran, Z. Dong, Z. Chen and X. Chen, Adv. Mater., 2014, 26, 6111.

46 Y. Zhang, A. Thomas, M. Antonietti and X. Wang, J. Am. Chem. Soc., 2008, 131, 50.

47 J. Liu, T. Zhang, Z. Wang, G. Dawson and W. Chen, J. Mater. Chem., 2011, 21, 14398.

48 G. Zhang, J. Zhang, M. Zhang and X. Wang, J. Mater. Chem., 2012, 22, 8083.

49 Y. Feldman, E. Wasserman, D. Srolovitz and R. Tenne, Science, 1995, 267, 222.

50 P. Afanasiev and I. Bezverkhy, Chem. Mater., 2002, 14, 2826.

51 Z. Ding, X. Chen, M. Antonietti and X. Wang, ChemSusChem, 2011, 4, 274.

52 X. C. Song, Y. Zhao, Y. F. Zheng and E. Yang, Adv. Eng. Mater., 2007, 9, 96.

53 J. Zhu, Y. Wei, W. Chen, Z. Zhao and A. Thomas, Chem. Commun., 2010, 46, 6965.

54 Z. Wen, S. Ci, Y. Hou and J. Chen, Angew. Chem., Int. Ed., 2014, 53, 6496.

55 B. Chakraborty, A. Bera, D. Muthu, S. Bhowmick, U. Waghmare and A. Sood, Phys. Rev. B: Condens. Matter, 2012, 85, 161403.

56 R. Yan, S. Bertolazzi, J. Brivio, T. Fang, A. Konar, A. G. Birdwell, N. Nguyen, A. Kis, D. Jena and H. G. Xing, arXiv preprint arXiv:1211.4136, 2012.

57 J. Ji, L. L. Zhang, H. Ji, Y. Li, X. Zhao, X. Bai, X. Fan, F. Zhang and R. S. Ruoff, ACS Nano, 2013, 7, 6237.

58 N. Liu, Z. Lu, J. Zhao, M. T. McDowell, H.-W. Lee, W. Zhao and Y. Cui, Nat. Nanotechnol., 2014, 9, 187. 